\title{
Developmental analyses of social play behavior in juvenile rats
}

\author{
D. H. THOR and W. R. HOLLOWAY, JR. \\ Edward R. Johnstone Training and Research Center, Bordentown, New Jersey
}

\begin{abstract}
Juvenile rats normally engage in rough-and-tumble social play behavior. Casual and informal reports of social play have been superseded by more detailed observations, including longitudinal studies of the developmental function from preweanling to young adult stages. Social play is first seen at 15 or 16 days of age. It then increases in frequency and vigor to a peak level at approximately 36 days of age. At puberty, social play behaviors of males merge into situationspecific behaviors related to copulation and aggression. In females, social play continues into sexual maturity. This review compares the available ontogenetic descriptions of social play in juvenile rats and specifies a number of informational gaps in the literature.
\end{abstract}

Social play, play fighting, or rough-and-tumble play behavior in juvenile rats varies systematically with chronological age. A variety of approaches to the assessment of age-related change in juvenile play have confirmed a systematic developmental function, usually described as an inverted U-shaped curve with maximum play at 30-40 days of age. This brief review compares the available reports to assess their individual and combined contributions.

Each study is outlined in Table 1. Interestingly, three are dated in the 1960s and eight are dated in the 1980s; none are from the 1970s. Among the earlier works, only that by Müller-Schwarze (1966) placed primary emphasis on social play behavior, and this publication was in the form of a one-page descriptive note. Only three of the nine later works emphasized the ontology of play fighting behavior (Panksepp, 1981; Takahashi \& Lore, 1983; Taylor, 1980). Number of animals observed varied from 6 (3 pairs) to 160 (40 litters). In several studies, only males were observed; in other studies, sex differences were examined (Meaney \& Stewart, 1981; Panksepp, 1981; Takahashi \& Lore, 1983). An early report by Bolles and Woods (1964) indicated no sex differences as well as no effects of size difference. But investigators have tended to defer to sex differences reported by Poole and Fish (1976) and by Seward (1945) and to concentrate their observations on the more "aggressive"' male juvenile (Taylor, 1980). Other investigators have observed juveniles of both sexes, have tested for sex differences, and have reported statistically nonsignificant results (Panksepp, 1981). Although Seward (1945) reported no statistically significant gender differences ["they were sufficiently marked to lead me to discard females and use only males in later experiments"' (p. 185)], he accurately described the rough-and-tumble social play observed in prepubertal animals and contrasted juvenile play fighting with adult

The authors' mailing address is: Edward R. Johnstone Training and Research Center, Bordentown, NJ 08505. aggression. Seward (1945) and Taylor (1980) were primarily concerned with the ontology of aggressive behavior.

\section{PROCEDURES}

A major difference among observational procedures is the degree to which the observer manipulates the social environment before, during, or after the observation interval. For example, Panksepp (1981) and Takahashi and Lore (1983) maintained each juvenile in a separate cage, except when juveniles were paired in a test chamber prior to test. Other investigators have preferred observational methods calling for minimal interference or disturbance (Bolles \& Woods, 1964; Meaney \& Stewart, 1981; Müller-Schwarze, 1966; Poole \& Fish, 1975, 1976). Panksepp (1981) compared isolate juveniles (individually housed) with group-housed juveniles when paired in a test chamber. Isolates engaged in significantly more play than nonisolates, and thus the shape of play fighting frequency distribution over days varied with housing condition. However, for both housing conditions, maximal play fighting occured at approximately the same age (28-40 days).

The observation by Panksepp and Beatty (1980) and by Taylor (1980) that social isolation promotes a large increase in play fighting is currently very well established. But the cause of this effect is unknown. Stevens (1981) found that olfactory and visual stimulation, without tactile interaction, was insufficient to eliminate isolationinduced increases in play. Similarly, contact with an anesthetized littermate failed to block the isolation effect. But periodic interaction with the experimenter's gloved hand was sufficient to eliminate the isolation effect. Length of the pretest social-isolation interval may be tailored for particular experimental applications (Stevens, 1981; Thor \& Holloway, 1984a). At present, there are no explicit contraindications for experimental applications of pretest social isolation as a convenient method for stimulating or 
Table 1

Ontogenetic Observations of Juvenile Social Play

\begin{tabular}{|c|c|c|c|c|c|c|c|}
\hline $\begin{array}{c}\text { Investigators } \\
\text { (year) }\end{array}$ & Strain & Sex & $\begin{array}{c}\text { Total } \\
\mathrm{n}\end{array}$ & $\begin{array}{c}\text { Per-Cage } \\
\mathbf{n}\end{array}$ & $\begin{array}{c}\text { Age } \\
\text { Observed* }\end{array}$ & $\begin{array}{l}\text { Peak Social } \\
\text { Play* }\end{array}$ & Measure \\
\hline $\begin{array}{l}\text { Seward } \\
(1945)\end{array}$ & Albino & $\mathrm{M} \& \mathrm{~F}$ & 18 & 2 & $35-212$ & $35-45$ & Dominance \\
\hline $\begin{array}{l}\text { Bolles \& Woods } \\
\text { (1964) }\end{array}$ & Sprague-Dawley & $\mathrm{M} \& \mathrm{~F}$ & 117 & 9 & $1-36$ & $22-29$ & $\begin{array}{l}\text { Pinning and } \\
\text { aggressive groom }\end{array}$ \\
\hline $\begin{array}{l}\text { Müller-Schwarze } \\
\text { (1966) }\end{array}$ & Wild trapped & $\mathbf{M}$ & 6 & 2 & $26-70$ & $38-42$ & $\begin{array}{l}\text { Play fighting } \\
\text { time }(\mathrm{sec})\end{array}$ \\
\hline $\begin{array}{l}\text { Baenninger } \\
\text { (1967) }\end{array}$ & $\mathbf{L a b} * *$ & $\mathbf{M}$ & 10 & 6 & $3-92$ & $30-36$ & $\begin{array}{l}\text { Fight, dominate, } \\
\text { and submit }\end{array}$ \\
\hline $\begin{array}{l}\text { Taylor } \\
(1980)\end{array}$ & Long-Evans & $\mathbf{M}$ & 160 & 4 & $14-109$ & $40-49$ & No. of playfights \\
\hline $\begin{array}{l}\text { Panksepp } \\
\text { (1981) }\end{array}$ & Long-Evans & $\mathrm{M} \& \mathrm{~F}$ & 58 & 2 & $18-64$ & $32-40$ & Pin frequency \\
\hline $\begin{array}{l}\text { Meaney \& Stewart } \\
(1981)\end{array}$ & Long-Evans & $M \& F$ & 24 & 6 & $21-55$ & $36-40$ & Pounce frequency \\
\hline $\begin{array}{l}\text { Stevens } \\
(1981)\end{array}$ & $\mathrm{Lab} * *$ & M\&F & 80 & 8 & $15-60$ & 60 & No. of playfights \\
\hline $\begin{array}{l}\text { Takahashi } \\
\text { (1982) }\end{array}$ & Long-Evans & $\mathbf{M}$ & 144 & 2 & $24-80$ & 24-32 & $\begin{array}{l}\text { Pin, box, threat, } \\
\text { bite, and groom }\end{array}$ \\
\hline $\begin{array}{l}\text { Holloway \& Thor } \\
\text { (1983) }\end{array}$ & Long-Evans & $\mathbf{M}$ & 40 & 2 & $24-84$ & 24 & Pin frequency \\
\hline $\begin{array}{l}\text { 'Takahashi \& Lore } \\
\text { (1983) }\end{array}$ & Long-Evans & $M \& F$ & 96 & 2 & $24-105$ & $30-36$ & $\begin{array}{l}\text { On-top postures } \\
\text { (pins) }\end{array}$ \\
\hline $\begin{array}{l}\text { Panksepp et al. } \\
\text { (1984) }\end{array}$ & Long-Evans & $\mathbf{M}$ & 16 & 2 & $28-43$ & $33-36$ & Pin frequency \\
\hline
\end{tabular}

*Age in days. $\quad * *$ Unspecified laboratory colony.

concentrating social play. A possible exception pertains to the analysis of sex differences, which may be more reliably demonstrated with the "focal observation" procedure (Altmann, 1974; Meaney \& Stewart, 1983). However, sex differences in measures of play fighting appear to be generally nonrobust (Thor \& Holloway, 1984a) and to vary with age (Meaney \& Stewart, 1981). Some evidence suggests that sex differences may be more readily evident in play-soliciting behaviors, males exhibiting a greater play-soliciting frequency than females (Thor \& Holloway, 1983).

\section{WHEN DOES PLAY FIGHTING BEGIN?}

Initial social play corresponds with the opening of the eyes and ears as well as with independent locomotion away from the nest site. Small (1899) first observed play at 18 days of age and suggested that by 25 days of age the entire play behavior repertory was apparent. More recently, social play was first observed on Days 15 and 16 (Bolles \& Woods, 1964), a finding confirmed by Baenninger (1967). Early play fighting was described by Meaney and Stewart (1981) as "appearing to erupt spontaneously between any two animals in proximity. The bouts did not appear to be initiated by one of the animals" (p. 43). Meaney and Stewart (1981) found no sex differences in play initiation (pouncing) during their earliest observation interval (21-25 days), but at all subsequent intervals (26-55 days) males were observed to initiate play more frequently than females. Poole and Fish (1976) reported that duration of play bouts increased with age, as younger juveniles withdrew from play bouts sooner than did older juveniles.

\section{WHEN IS PLAY FIGHTING MOST PROMINENT?}

A number of observers have remarked on the consistency of social play throughout the juvenile interval (Meaney \& Stewart, 1981; Poole \& Fish, 1976); that is, the form of social interaction is quite similar throughout. Individual differences in social play, however, become more pronounced with increasing age (Taylor, 1980). Males engage in more frequent play encounters than do females, and males are more likely to engage in play with other males than with females (Meaney \& Stewart, 1981; Poole \& Fish, 1976). Maximum social play occurs at a peak of approximately 36 days of age, or at approximately the midpoint of the periadolescent period (7-10-day period prior to the onset of puberty), which has been described as a time of hyperactivity, behavioral anomalies, and unusual psychopharmacological response (see Spear \& Brake, 1983).

The incidence of play fighting over age is described in Figure 1 . This curve is a composite of mean data reported by several investigators (Baenninger, 1967; Panksepp, 1981; Müller-Schwarze, 1966; Takahashi \& Lore, 1983). A relatively rapid increase in social play is followed by a gradual decline. As a rule of thumb, social play increases from its inception at 15 days of age to about 30 days of 


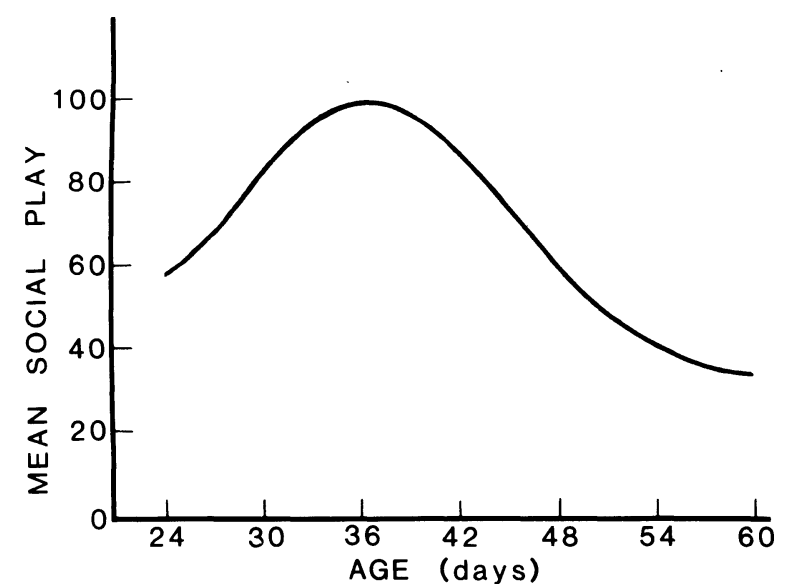

Figure 1. Frequency of observed social play in young male and female rats as a function of age. A composite of longitudinal observations fitted to a common ordinate scale.

age. Play frequency is then relatively high for approximately 10-15 days, at which time it decreases to a level less than half that of peak level.

\section{WHEN DOES SOCIAL PLAY WANE?}

Young adult rats commonly engage in most of the specific acts that collectively define play fighting. Social play is thus described as merging into a variety of adult forms of behavior that are more situation specific (Meaney \& Stewart, 1981). When observed in heterosexual groups, male social play is gradually displaced by behaviors that are more explicitly sexual (mounting) or overtly aggressive (biting). Onset of sexual receptivity in females (at 41 to 50 days of age) corresponds with an increase in mounting by males. Preference of younger male juveniles for young males as play partners shifts to young females between 36 and 40 days of age.

Takahashi and Lore (1983) recently reported that social play in female pairs and in heterosexual pairs continues until 90 days of age (or later) at levels comparable to those observed at 48 days of age. In male pairs, social play was observed to peak at 30 days of age and to decline thereafter. Female and heterosexual pairs engaged in reliably more play than male pairs from 60 to 90 days of age; in male pairs, play was observed to terminate following overt aggressive behavior. Takahashi and Lore (1983) did not comment on sexual interactions or changes in the play behavior of females associated with onset of sexual receptivity. Prolonged social isolation, as in the Takahashi and Lore (1983) study, may also have significant effects on social interactions; Meaney and Stewart (1981), for example, cited several references suggesting abnormal social behaviors in rats maintained as isolates throughout the juvenile period (weaning to sexual maturity). Elsewhere, Einon, Morgan, and Kibbler (1978) reported that $1-\mathrm{h}$, daily social exposures of an isolate juvenile to another juvenile alleviated some deleterious effects of isolation.
Taylor (1980) proposed that juvenile play fighting is an immature form of aggressive behavior. Recent evidence, however, indicates that the biological variables governing juvenile social play may be independent of those governing adult social aggression. For example, juvenile social play is affected by the perinatal, organizational effects of androgens and is unaffected by subsequent exposure to androgens (Beatty, 1984). Meaney and Stewart (1983) found that juvenile males receiving daily testosterone injections from 26 to 40 days of age did not engage in more social play than controls. In contrast, adult male aggression is intimately associated with both organizational and activational effects of androgens.

\section{SUMMARY AND CONCLUSIONS}

In view of the potential for understanding the general phenomenon of social play, the current literature consists of only a handful of reports that deal specifically with the ontology of social play. A number of supplementary reports include descriptions of social play at varying ages. There are no longitudinal studies of social play in neonatally castrated males, Tfm (testicular feminization mutation) males, neonatally ovariectomized females, or neonatally androgenized females. Similarly, there are very few longitudinal studies of social play in juveniles or young adults chronically exposed to hormones or drugs (Panksepp, Siviy, \& Normansell, 1984; Thor \& Holloway, 1984b).

The available literature is uniform in describing the general shape of the relationship of play frequency to age. Peak juvenile play occurs during periadolescence, that is, the 7-10-day interval prior to puberty. Social play in postpubertal females and in heterosexual pairs has been described but remains a relatively unexplored area. Comparisons of pre- and postpubertal effects of treatments may be exploited to yield new insights concerning developmental interactions.

Although central to scientific generalization, there is no comprehensive theory associated with the developmental analysis of social play in juvenile rats; and, in contrast to description, there is no substantive neurobiological analysis of play exclusive of the organizational effects of gonadal hormones. Similarly, there are no unequivocal analyses of the importance of play for the individual or the group. Presumably, any ubiquitous social behavior that incurs a substantial energy cost as well as a heightened exposure to predators will have significant adaptive benefits (see Fagen, 1977, 1981).

\section{REFERENCES}

AltmanN, J. (1974). Observational study of behavior: Sampling methods. Behaviour, 49, 227-267.

BAENNINGER, L. P. (1967). Comparison of behavioural development in socially isolated and grouped rats. Animal Behaviour, 15, 312-323.

BEATTY, W. W. (1984). Hormonal organization of sex differences in play fighting and spatial behavior. In G. J. De Vries, J. P. C. De Bruin, H. B. M. Uylings, \& M. A. Corner (Eds.), Progress in 
brain research: Vol. 61. Sex differences in the brain. Amsterdam: Elsevier.

Bolles, R. C., \& Woods, P. J. (1964). The ontogeny of behaviour in the albino rat. Animal Behaviour, 12, 427-441.

Einon, D. F., Morgan, M. J., \& KibBleR, C. C. (1978). Brief periods of socialization and later behaviour in the rat. Developmental Psychobiology, 11, 213-225.

FAGEN, R. M. (1977). Selection for optimal age-dependent schedules of play behavior. American Naturalist, 111, 395-414.

FAGEN, R. (1981). Animal play behavior. New York: Oxford University Press.

Holloway, W. R., JR., \& ThOR, D. H. (1983). Caffeine: Effects on the behaviors of juvenile rats. Neurobehavioral Toxicology and Teratology, 5, 127-134.

Meaney, M. J., \& STewart, J. (1981). A descriptive study of social development in the rat (Rattus norvegicus). Animal Behaviour, 29, 34-45.

Meaney, M. J., \& StewarT, J. (1983). The influence of exogenous testosterone and corticosterone on the social behavior of prepubertal male rats. Bulletin of the Psychonomic Society, 21, 232-234.

Müller-SCHWARZE, D. (1966). Experimente zur Triebspezifität des Säugetierspeils. Naturwissenshaften, 53, 137-138.

Panksepp, J. (1981). The ontogeny of play in rats. Developmental Psychobiology, 14, 327-332.

Panksepp, J., \& BeatTy, W. W. (1980). Social deprivation and play in rats. Behavioral and Neural Biology, 30, 197-206.

Panksepp, J., SiviY, S., \& Normansell, L. (1984). The psychobiology of play: Theoretical and methodological considerations. $\mathrm{Neu}$ roscience and Biobehavioral Reviews, 8, 465-492.

Poole, T. B., \& FISH, J. (1975). An investigation of playful behaviour in Rattus norvegicus and mus musculus (Mammalia). Journal of the Zoological Society (London), 175, 61-71.
Poole, T. B., \& Fish, J. (1976). An investigation of individual, age and sexual differences in the play of Rattus norvegicus (Mammalia: Rodentia). Journal of the Zoological Society (London), 179, 249-260.

SEWARD, J. P. (1945). Aggressive behavior in the rat: I. General characteristics; age and sex differences. Journal of Comparative Psychology, 38, 175-197.

Small, W. S. (1899). Notes on the psychic development of the young white rat. American Journal of Psychology, 11, 80-100.

SPEAR, L. P., \& BRAKe, S. C. (1983). Periadolescence: Age-dependent behavior and psychopharmacological responsivity in rats. Developmental Psychobiology, 16, 83-109.

STEVENS, S. (1981). Play behavior in Rattus norvegicus: Development of research methods and an analysis of play deprivation. Unpublished doctoral dissertation, Indiana University, Bloomington.

TAKAHASHI, L. K. (1982). Early environmental and social influences on agonistic behavior in adult laboratory rats. Unpublished doctoral dissertation, Rutgers University, New Brunswick, NJ.

TAKAHASHI, L. K., \& LORE, R. K. (1983). Play fighting and the development of agonistic behavior in male and female rats. Aggressive Behavior, 9, 217-227.

TAYLOR, G. T. (1980). Fighting in juvenile rats and the ontogeny of agonistic behavior. Journal of Comparative and Physiological Psychology, 94, 953-961.

ThOR, D. H., \& Holloway, W. R., JR. (1983). Play-solicitation behavior in juvenile male and female rats. Animal Learning \& Behavior, 11, 173-178.

ThOR, D.H., \& Holloway, W. R., JR. (1984a). Sex and social play in juvenile rats (Rattus norvegicus). Journal of Comparative Psychology, 98, 276-284.

ThOR, D. H., \& Holloway, W. R., JR. (1984b). Social play in juvenile rats: A decade of methodological and experimental research. Neuroscience and Biobehavioral Reviews, 8, 455-464. 